W.P. 07-15

\title{
The international transmission of monetary shocks in a dollarized economy: \\ The case of USA and Lebanon
}

Jean-François Goux, Charbel Cordahi

Juillet 2007

GATE Groupe d'Analyse et de Théorie Économique

UMR 5824 du CNRS

93 chemin des Mouilles - 69130 Écully - France

B.P. $167-69131$ Écully Cedex

Tél. +33 (0)4 72866060 - Fax +33 (0)4 72866090

Messagerie électronique gate@gate.cnrs.fr

Serveur Web : www.gate.cnrs.fr 


\title{
The international transmission of monetary shocks in a dollarized economy: The case of USA and Lebanon
}

\author{
Jean François GOUX \\ Full Professor \\ GATE (CNRS) and Université Lumière Lyon 2 \\ Email: goux@gate.cnrs.fr \\ Charbel CORDAHI \\ Associate Professor \\ Université Saint Esprit de Kaslik (USEK), Kaslik \\ Email: charbelcordahi@usek.edu.lb
}

January 2007

\begin{abstract}
$\underline{\text { Abstract }}$
We show that an American monetary shock wields an influence, though limited, over the Lebanese output in accordance with the literature advances. However, as we are waiting for a stronger transmission of U.S. short-term rates to Lebanese short-term rates, we notice that this transmission is weak in the first year. The result can be explained by the presence of pricing-to-market. After the end of the first year, we find the traditional result where the increase in the American interest rate is transmitted integrally to the Lebanese interest rate. We recognize this phenomenon as the dollarization effect.

JEL classification : $\quad \mathrm{E} 3 ; \mathrm{E} 4 ; \mathrm{F} 3 ; \mathrm{F} 4$

Keywords: International transmission, monetary shock, interest rate, pricing-to-market, law of one price, purchasing power parity.

Mots-clefs : $\quad$ transmission internationale, choc monétaire, taux d'intérêt, loi du prix unique, parité des pouvoirs d'achat
\end{abstract}




\section{Introduction}

In this article, we study the international transmission of monetary shocks in the case of a dollarized economy. We have chosen as a case study the United States and Lebanon.

After a review of the theory and the empirical analyses of international transmission of monetary shocks, and an analysis of dollarization, we study the international transmission of American monetary shocks to the Lebanese economy with the help of an econometric model.

We show that an American monetary shock wields an influence, though limited, over the Lebanese output in accordance with the literature advances. However, as we are waiting for a stronger transmission of U.S. short-term rates to Lebanese short-term rates, we notice that this transmission is weak in the first year. The result can be explained by the presence of pricing-to-market. After the end of the first year, we find the traditional result where the increase in the U.S. interest rate is transmitted integrally to the Lebanese interest rate. We recognize this phenomenon as the dollarization effect.

In Section (2), we reexamine the theory and empirical analyses of the international transmission of monetary shocks. In Section (3), we study the dollarization. In Section (4), we construct a VAR model of the Lebanese economy and draw conclusions on the international transmission of U.S. monetary shocks to the Lebanese economy.

\section{The theory and empirical analyses of the international transmission of monetary shocks}

Despite the fact that the economists had favored the study of international transmission of monetary shocks in an open economy ever since the development of the Mundell-Fleming-Dornbusch model (Dornbusch, 1976), there is no real consensus on the framework to be adopted. Even if most researchers examine the issue in light of fluctuating exchange rates and producers' currency pricing, others defend the necessity to integrate monopolistic competition and sales policies, mainly the pricing-to-market (or PTM). Another aspect of international transmission, which has not yet been fully addressed, is that of the dollarization (which will be explained further in Section 3 of the article).

In this Section, we first present the traditional analyses of international transmission of monetary shocks. After that, we expand on updated analyses and finally display the results of empirical work. 


\subsection{Traditional Analyses}

The small open economy model of Mundell-Fleming-Dornbusch has continued to be of influence in academic and political circles till the mid 1990s. However, some questions started to pop up in the 1980s, primarily regarding agent preferences, technology and long-term budget constraints.

The incorporation of microeconomic aspects and monopolistic competition has allowed Obstfeld and Rogoff (1995) to reexamine Mundell's results, to integrate inter-temporal maximization in the analysis of monetary shocks, and to advance the MFD model toward a dynamic approach.

The incorporation of microeconomic aspects clarifies, more specifically, the models of international transmission of monetary shocks. Likewise, the adoption of the neo-Keynesian principle of imperfect competition allows the New Open Economy Macroeconomics to oppose the role played by the perfect competition in the transmission (where the agents are price-takers) and gives the monopolistic power of enterprises the possibility to affect price decisions.

According to the inter-temporal approach, the current account of a small open economy is not influenced by international shocks and its reaction to national shocks depends on the persistence of those.

Obstfeld and Rogoff (1995) assume that the purchasing power parity (PPP) always holds. As a result, the real interest rate parity holds in the two countries.

By integrating microeconomic aspects and inter-temporal utility maximization in the study of international transmission of monetary shocks, the role of the interest rate is established. Following a monetary shock in the domestic country Nation, the national and foreign real interest rates decrease ${ }^{1}$. The exchange rate depreciates and the trade balance improves due to the expenditure-switching effect of the nominal exchange rate change. A country with a depreciating currency will experience a fall in the relative price of its exports and a resulting redirection of world expenditure in favor of its products. Consequently, the national output increases and the foreign output decreases.

Selling prices are preset in the currency of the producing country. When the exchange rate varies, the prices set by the producing country expressed in foreign currency vary as well. The current account of Nation can register surpluses that continually increase the stock of domestic assets in comparison with the stock of foreign assets. The effects of monetary shocks can therefore last beyond the time needed for the adjustment of nominal rigidities. Accordingly, monetary shocks wield long-term effects.

\footnotetext{
${ }^{1}$ The decrease of real interest rates leads to an increase in national and foreign consumptions.
} 
While switching from the MFD model to the Obstfeld and Rogoff model (1995), the overshooting of nominal exchange rate disappears. The exchange rate directly passes to its new level of long-term equilibrium despite the rigidity of prices.

Upon studying the effects of a non-anticipated and permanent increase of domestic money supply, Obstfeld and Rogoff (1995) state that this increase induces a growth in national output and in consumption. The world interest rate decreases, and the depreciation of the nominal exchange rate is expressed by a depreciation of the terms of trade. The foreign consumption increases. However, the impact of monetary shock on the foreign output is unclear, because the aggregate consumption and the relative prices vary in opposite directions. Meanwhile, the domestic current account registers a surplus.

An important characteristic in the Obstfeld and Rogoff model is the interpretation given to the nominal price rigidity. This rigidity is an exogenous trait due to the environment (Blinder, 1994), (Dornbusch, 1976). With Obstfeld and Rogoff, the nominal rigidity becomes the concern of firms, which simultaneously set their prices in advance.

\subsection{Updating analyses}

One of the characteristics of traditional approaches is that the law of one price always holds. This assumption, rejected in fact by Engel (1999), Engel and Rogers (1996), and many other researchers, has paved the way for different explanations of the PPP deviation, and has allowed the integration of market segmentation and PTM in the study of the international transmission of monetary shocks.

The integration of the PTM in the Obstfeld and Rogoff model allows us to be aware of the hypothesis according to which the exports can be priced in a foreign currency. It provides a solid explanation to the deviation from the law of one price for tradable goods. It equally modifies the results of the international transmission, which are no longer based on the structure of the assets market but on the currency used for pricing and on the degree of PTM.

The PTM reduces the transmission of exchange rate variations to the selling prices, hinders the expenditure-switching effect, and increases the national and foreign outputs. It also increases the instability of the exchange rate and causes deviations from purchasing power parity.

Consequently, the depreciation of a country's currency improves its terms of trade. When the PTM is total, the export prices expressed in domestic currency increase, while the import prices remain constant. As a result, the depreciation of the exchange rate improves the national output and deteriorates the foreign output.

The Betts and Devereux $(1999,2000)$ models allow the study of the effects of PTM on the international transmission of monetary shocks. These models are an extension of Obstfeld and Rogoff (1995) model, 
which integrate the segmentation of markets and the sales taking place in the currency of the purchasing country. For Betts and Devereux, the arbitration between the markets is not possible and the short-term selling prices are rigid. Moreover, the PTM causes deviations from the purchasing power parity. The Betts and Devereux models are based on profit utility and maximization within an inter-temporal framework, as well as on the establishment of budget constraints for all agents. To simplify their analysis, these two researchers did not make any distinction between monetary and budgetary authorities. From the formalization point of view, there are two countries in the model. In each country, the households offer work and consume a basket of various goods. A proportion ( $n$ ) of these goods are made in the domestic country Nation and a proportion $(1-n)$ is made abroad. The respective populations of Nation and Abroad are represented by $(n)$ and $(1-n)$. Every good is exclusively sold by a firm, which set the selling price. A part (s) of the firms in each country can implement price discrimination between the countries. Since the PTM firms are the only ones that can market the goods in question, they set different prices for the national and foreign markets. The other goods $(1-s)$ can be freely exchanged by the consumers, which incite the firms to set a single selling price for these goods in the two countries.

A non-anticipated variation in the exchange rate causes a deviation to the law of one price, which requires $(p=e q)$. To avoid the possibility of arbitration stemming from this deviation, "the firm must be able to segment its home and foreign markets" ${ }^{2}$. When the markets are integrated, the price elasticity of demand is equal to any point on the markup ratio $(\lambda)$. The choice of the current price affects the future profits anticipated by the firm. The latter must face the problem of pricing in order to maximize its profits. When the markets are less integrated, the objective function is less clear. The firms set their prices in a manner that allows them to maximize the current value of anticipated profits.

Following a domestic monetary shock, the nominal and real interest rates decrease in PTM. The real exchange rate reacts to a non-anticipated monetary shock because the purchasing power parity doesn't hold on the short term. Immediate real and nominal currency depreciation is produced and the nominal exchange rate overshoots. The spread of nominal interest rates diminishes in this case and the real exchange rate increases. The exchange rate fluctuations are not directly transmitted to the selling price, and the deviations from the PPP lead to an inequality in the two countries' interest rates. Thus, according to Betts and Devereux (1999), "home real interest rates fall, while foreign rates rise slightly"3.

Betts and Devereux (2000) obtain complementary results. They show that the real domestic interest rate always diminishes after a monetary shock within Nation. When (s) increases, the repercussion of the exchange rate variations on the export price decreases, and the effect of monetary shock on foreign consumption weakens while the effect on the domestic consumption intensifies. When (s) tends to (1),

\footnotetext{
${ }^{2}$ Betts and Devereux (1999), page 17.

${ }^{3}$ Betts and Devereux (1999), page 31.
} 
"the domestic real interest rate falls" . The decrease of the real interest rate following a monetary shock modifies the long-term consumers' behavior. The inhabitants of Nation wish to keep a part of their supplementary income to be consumed subsequently, but the decrease in the real interest rate stimulates them to consume at the present time all their income. Just as the markets are segmented by country, the real ex-post interest rates are not equal in the two countries, and the foreign interest rate is invariant. For that reason, the real domestic interest rate, which is lower, does not encourage foreigners to borrow more. Hence, the monetary shock does not wield an impact over the trade balance while the PTM is total. Consequently, the effect of the monetary shock on future production decreases while (s) tends to (1). When the purchasing power parity is verified, the nominal exchange rate overshoots (Betts and Devereux, 1999) and the nominal domestic interest rate decreases. The nominal foreign interest rates remain constant.

The PTM models were criticized. Some researchers, like Obstfeld and Rogoff (2000) believe that the correlations between the terms of trade and the exchange rates are due to nominal rigidities and not to PTM. As a result, the pass-through from exchange rates to export prices is not nil, and the depreciation of a country's currency drops its terms of trade. Accordingly, the national currency is the main currency the exporters use to set their selling prices abroad. Cordahi (2005) shows that some countries (like the United States) adopt their own currency for their exports, and that others (like Japan) adopt the currency of the purchasing country. A third group of countries (France, United Kingdom, Germany...) adopt a hybrid approach.

Otani (2002) incorporated the international price-setting behavior in the study of the international transmission of monetary shocks. His work shows that the effects of monetary shocks differ perceptibly when the national and foreign firms adopt different pricing behaviors. Therefore, the effects of Japanese monetary shocks on the rest of the world are limited because the Japanese firms adopt the PTM in their foreign trade. On the other hand, U.S. monetary shocks affect the rest of the world because American firms transfer the total fluctuations of the dollar to their prices.

From the formalization point of view, instead of assuming, like Betts and Devereux (1996, 1999, 2000, 2001), that a part (s) of national and foreign firms set their export prices in the purchasing country's currency, Otani believes that a part $\left(s^{1}\right)$ of domestic firms and a part $\left(\mathrm{s}^{2}\right)$ of foreign firms adopt the PTM. The share of goods and PCP firms in Nation becomes $\left(1-s^{1}\right)$ and the part of goods and PCP firms abroad becomes $\left(1-s^{2}\right)$. This method confirms the hypothesis according to which some countries adopt the PTM more than others and allows the generalization of the analytic framework of "pricing-to-market", including that of Obstfeld and Rogoff (1995) where $\left(s^{1}=s^{2}=0\right)$ and that of Betts and Devereux (1999, 2000) where $\left(s^{1}=s^{2}\right)$.

\footnotetext{
${ }^{4}$ Betts and Devereux (2000), page 18.
} 


\subsection{The Empirical Analyses}

Macroeconomic studies reveal that the foreign interest rate decreases in general after a domestic money supply shock. If the domestic economy is big enough to influence world economy, the decrease in the national interest rate carries with it a decrease in the international interest rate (Mundell-Fleming). Consequently, the foreign interest rate decreases. We find similar results in Kim (2001), Stockman and Obstfeld (1985), and Kollmann (1999).

\section{ㄱe international transmission of U.S. monetary shocks}

American monetary shocks have a positive effect on the international interest rate, which decreases. The decrease of this rate stimulates, according to Kim (2001), the international demand for current goods and services.

Kim (2001) examines the different models in the literature and studies the mechanism of international transmission of monetary shocks without a predefined theoretical framework. His study focuses on the effects of money supply shocks. Based on the empirical results he obtains, he evaluates the relevance of the theoretical models, in particular the MFD model and the inter-temporal models of Svensson and Wijnbergen (1989) and Obstfeld and Rogoff (1995).

In his model, Kim (2001) studies the international transmission of U.S. monetary shocks under a floating exchange rate regime with the help of a VAR model. These monetary expansions primarily cause economic booms in other countries. Within this transmission, changes in the trade balance play a minor role, while the decrease in the international interest rate plays a very important role. The American monetary growth weakens, secondly, the American trade balance throughout almost one year, but strengthens it later on.

Kim deals with empirical data. First, he studies the effects of monetary shocks on the trade balance and the foreign output. Afterwards, he deduces the mechanism of real transmission by analyzing the effects of monetary shocks on other variables (terms of trade, real interest rates, etc.). His model uses minimal identifying restrictions and does not depend much on a specific theoretical model. He uses newly developed models to identify monetary shocks. These models follow the VAR methodology for 
identifying monetary shocks, like for example Christiano and alii (1996) and Kim (1999). He applies the marginal method and adds each international and foreign variable to the base model, one after the other. In that way, he obtains more precise estimates and reaches a better understanding of the effects of a large number of variables without confronting possible arbitrariness and the complexity of modeling international interdependence. He examines subsequently the reliability of the results by adding two or three variables simultaneously and allowing some international interactions. He experiments as well with many identification schemes, including both recursive and non-recursive schemes, because in other studies, different identification schemes produced different results.

He shows that U.S. monetary expansion has a positive impact on non-U.S. G-6 output. This positive spillover occurs through the international capital market. A monetary growth in a large open economy reduces the real international interest rate and stimulates the world aggregate demand on current goods and services of both U.S. and non-U.S. countries. Despite the fact that American monetary expansion leads to a medium-run or long-term improvements in the U.S. trade balance and to a possible deterioration in the foreign trade balance, like the case of the MFD model, the magnitude of trade balance variations is small to ensure the phenomenon "beggar-thy-neighbor" aspect of monetary expansion.

On the whole, the U.S. interest rate decreases after an American monetary expansion. Knowing that the United States is a large open economy, the decrease in the U.S. real interest rate leads to a decrease in the real international interest rate if the world capital market is integrated to some extent. For Eichenbaum and Evans (1995) and Kim and Roubini (2000), a month passes before the foreign interest rates fall. The decrease in the interest rate increases the demand for current consumption and current goods, because the drop of the interest rate means that the current goods have become relatively cheaper than the future goods. The drop of the real interest rate also stimulates the current investment demand by lowering its present opportunity cost. Similarly, for Kim, "the decrease in the real world interest rate raises the world demand for consumption and investment. Consumption and investment (therefore, output) in both the U.S. and non-U.S. countries may increase since the real interest rate fall in both the U.S. and non-U.S. countries"

\footnotetext{
${ }^{5}$ Kim (2001), page 19.
} 


\section{Graph (1): Impulse response of the real aggregate interest rate of the non-U.S. G-6 countries to a}

\section{U.S. monetary shock (4 years)}

(a $1 \%$ non-anticipated rise of U.S. money supply)

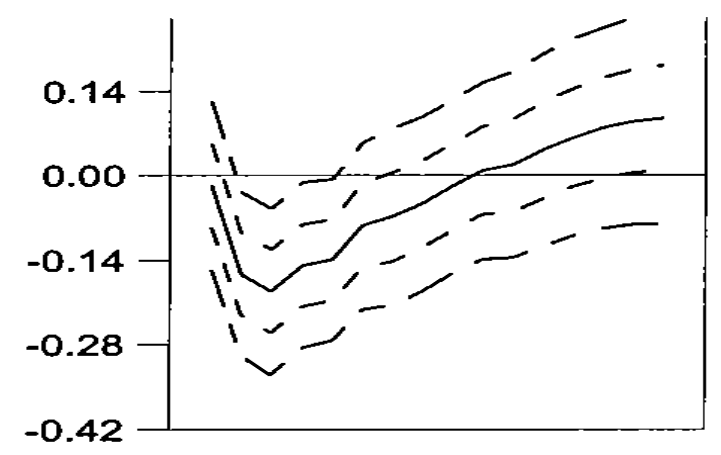

Source: Kim (2001), figure 5

\section{\International policy coordination and policy endogeneity}

For some researchers, for example Grilli and Roubini (1995) and Faust and alii (2003), the non-U.S. G-6 monetary policies are closely connected to the American monetary policy, and that is why these countries' interest rates vary after an increase (or decrease) in the United States money supply. On the other hand, Kim and Roubini (2000) show that the positive variations of the Fed fund rate lead to a substantial and significant increase in the non-U.S. G-6 interest rates, independently from the mechanism of international transmission. Faust and alii (2003) go further in their study and assume that central banks of other countries change their policies in light of the Fed decisions.

To examine the possible foreign policy endogeniety, Kim (2001) studies the reactions of the non-U.S. G6 short-term interest rates and monetary aggregates. A slight decrease appears in the interest rate. This decrease of $0.02 \%-0.13 \%$ is very small compared to the $0.5 \%-0.6 \%$ decrease of the American interest rate. In addition to that, the monetary aggregates do not increase in all the models. Hence, for Kim, “' "the non-U.S., G-6 countries do not seem to react strongly to U.S. monetary policy" ${ }^{\prime 6}$. The previous results on the international transmission of monetary shocks are therefore relevant.

Kim's results contradict the conclusions of Grilli and Roubini (1995) and Faust and alii (2003) that suggested that non-U.S. G-7 countries closely follow the U.S. monetary policy. In fact, these studies have not isolated the exogenous factors of the U.S. monetary policy, and they have not controlled the inflationary pressure or supply shock. Accordingly, the variations of the Federal fund rate could explain inflationist shocks or money supply shocks which may also affect other countries as well.

\footnotetext{
${ }^{6} \operatorname{Kim}(2001)$, page 18.
} 
Kim (2001) controls these shocks by adding a commodity price index to the system, and finds out that the endogenous reaction of the non-U.S. monetary policy to U.S. monetary policy is not important. With the intention of verifying the results, he uses monthly data and shows that the decrease in the short-term foreign interest rate is not important. Upon adding two variables to the system, he reaches similar results. Using non-recursive systems, he also shows that the foreign interest rate continues to decrease slightly (the American money supply remains constant). This proves, from his point of view, that "non-U.S. monetary authority does not strongly follow U.S. monetary policy"”.

\section{Dollarization}

Dollarization, which is increasingly the defining characteristic of many emerging market economies, presents two problems. On the one hand, it is an obstacle to monetary control and disinflation ${ }^{8}$. On the other hand, it increases the transmission of exchange rates fluctuations to import prices. This concern of having the prices vary with the fluctuations of exchange rates reinforces the fear of floating for highly dollarized economies and pushes them to adopt a regime of fixed parity.

In this Section, we study first the relation between dollarization and fixed exchange rate regime, passing by the pass-through. Secondly, we study the partial dollarization of the Lebanese economy.

\subsection{From dollarization to fixed exchange rate regime, passing by the pass-through}

The strong pass-through from exchange rate to import prices within a dollarized economy is verified by Reinhart and alii (2003), who study several categories of dollarized economies and show, for the period extending from January 1996 to December 2001, that "the pass-through from exchange rate to prices was

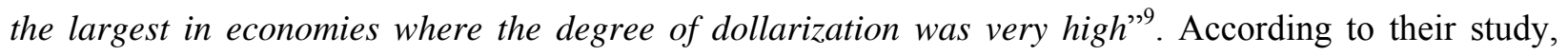
Lebanon is one of the most dollarized countries in the world (we shall come back to this topic in 3.2). Recent theories of fear of floating identify "a high pass-through coefficient as one key reason why central banks in emerging economies exhibit little tolerance to large exchange rate changes" ${ }^{\prime 10}$. The exchange rate regimes studied by Reinhart and alii show that the relation is strong between the fear of floating and

\footnotetext{
${ }^{7}$ Kim (2001), page 23.

8 This vision, shared by a large number of economists, like Balino and alii (1999), Ortiz (1983), Ramirez-Rojas (1985), etc., is established on the basis of theoretical results centering on currency substitution. Most of these studies focus on the dollarization in emerging countries (particularly in Latin America) in times of acute inflation. Reinhart and alii (2003) criticize the hypothesis in question and show that, contrary to the advances of the literature, the dollarization does not hinder monetary control and disinflation.

${ }^{9}$ Reinhart and alii (2003), page 38.

${ }^{10}$ Reinhart and alii (2003), page 51.
} 
the degree of dollarization of an economy. Reinhart and alii show that the higher the level of dollarization in the economy, the weaker the flexibility of the exchange rate and the more meaningful the fear of floating. This thesis is also supported by Calvo and Mishkin (2003) according to whom "policymakers in emerging market economies are very sensitive to the exchange rate because such economies often exhibit a high pass-through coefficient; that is, devaluation often leads to inflation" ${ }^{\prime 1}$. Gonzalez (2000) and Hausmann et alii (2001) defend, in their turn, this point of view.

The association of the dollarization with the fear of floating results from the new theoretical literature on liability dollarization. According to this theory, the private sector debts in foreign currency (liability dollarization) will tend to make countries less tolerant to large exchange rate changes, "out of concern of the adverse effects those changes may have on sectoral balance sheets and, ultimately, on aggregate output" ${ }^{12}$. For Calvo and Reinhart (1999), "most emerging market countries start from a situation of partial dollarization (at the very least, liability dollarization) and they rarely ignore exchange rate volatility completely"13. These two arguments strengthen one another. The partial dollarization increases the cost of exchange rate volatility and compels the central bank to intervene in order to prevent fluctuations in the nominal exchange rate. Calvo and Reinhart confirm that "this "fear of floating" may be so severe that the exchange rate spends long stretches of time at a fixed level" ${ }^{14}$. Besides, the fear of floating leads to a stronger liability dollarization, creating as a result a vicious circle from which it would be difficult to get out. Moreover, the fear of floating arises where firms use raw materials or foreign merchandise.

In the Lebanese case, which we will be studying more in detail in (3.2), the fixed parity system can be attributed, just like for other emerging countries, to the strong transmission of exchange rate fluctuations to import prices (due to the strong dollarization of the economy) and to the liability dollarization in the public and private sectors. These concerns, supported by the inflationist experience of public and private economic agents between 1984 and 1992, have compelled the monetary authorities since 1992 to adopt a dollar - Lebanese Pound fixed parity system.

We saw that the emerging countries, troubled by the effects of the dollarization on the pass-through to import prices, adopt a fixed parity regime. The adoption of such a regime counters the concerns of these countries because it considerably reduces the level of pass-through to import prices and leads in fact to a PTM regime (from the importers' side). Furthermore, Reinhart and alii (2003) show that a high degree of dollarization is not an obstacle to monetary control and that "high dollarization can indeed co-exist with low inflation; dollarization does not preclude monetary policy from attaining, and maintaining, its

\footnotetext{
${ }^{11}$ Calvo and Mishkin (2003), page 22.

${ }^{12}$ Reinhart and alii (2003), page 21.

${ }^{13}$ Calvo and Reinhart (1999), page 1.

${ }^{14}$ Calvo and Reinhart (1999), page 3.
} 
primary goal" ${ }^{\prime 15}$. These results are confirmed by Guidotti and Rodriguez (1992), Mueller (1994), Savastano (1996), Mongardini and Mueller (2000), Havrylyshyn and Beddies (2003), and many other researchers, who show that large and sustained falls in inflation rate in emerging countries do not go hand in hand with the decrease of domestic dollarization. A country can reach its monetary objectives even if the degree of dollarization is high.

The thesis, according to which the adoption of a fixed parity regime leads to a decrease in the passthrough to import prices is defended by Reinhart and alii (2003), who shows that "in the majority of dollarized economies - i.e., in the 66 countries where the degree of dollarization was either high or moderate between 1996-2001 - the pass-through coefficient is about 0.5" ${ }^{16}$. The pass-through coefficient estimated by Reinhart and alii is similar to Kamin's result (1998). The latter uses a similar equation of the pass-through coefficient and the same sample of countries as Reinhart and alii, with longer time series. He concludes that the pass-through coefficient is 0.5 or higher. In their turn, Honohan and Shi (2002), who use a longer time series than that of Reinhart and alii, but who use the same specification equation and the same sample of countries, find an average pass-through coefficient of 0.3 . For the highly dollarized countries (including Lebanon), Reinhart and alii find that the pass-through coefficient rises to 0.49 for the period extending from January 1996 to December 2001. For these three researchers, the fact that the passthrough coefficients in the dollarized emerging countries are identical to those observed in developing economies reveals that "these results are broadly supportive of one central premise of the hypothesis of "fear of floating”, namely, that a high pass-through coefficient is one of the reasons why central banks have little tolerance for large exchange rate changes"17. Reinhart (2000) asserts that "countries that say they allow their exchange rate to float mostly do not - there seems to be an epidemic case of "fear of floating""'18. For Gonzalez (2000), when the dollarization is associated with a fixed parity regime, the pass-through is controlled.

\subsection{The partial dollarization of the Lebanese economy}

We have already indicated in section 3.1 that the Lebanese economy is dollarized. This characteristic of Lebanon determines the evolution of monetary aggregates in the country and largely affects the international transmission of monetary shocks to the domestic sphere. It equally leads to the rigidity of domestic prices and to the adoption of the pricing-to-market behavior by the importers.

\footnotetext{
${ }^{15}$ Reinhart and alii (2003), page 23.

${ }^{16}$ Reinhart and alii (2003), page 39.

${ }^{17}$ Reinhart and alii (2003), page 39.

${ }^{18}$ Reinhart (2000), page 2.
} 
Dollarization is not restricted to Lebanon. In many emerging economies, governments borrow in dollars or other foreign currencies, agents hold bank accounts made out in currencies other than their national currency, firms and the public sector borrow both at the national and international levels, etc. ${ }^{19}$

For Mueller (1994), who has studied the case of Lebanon between 1982 and 1993 from an econometric point of view, the high dollarization is due to the anticipated depreciation of the exchange rate and to the spread of interest rates over the dollar between Lebanon and the United States.

Reinhart and alii (2003) study the dollarized economies (excluding the officially dollarized countries and the industrial countries). They construct a composite index of dollarization for each country in the sample, and classify the countries into four categories on the basis of their dollarization "type". The composite index includes: bank deposits in foreign currency as a share of broad money, total external debt as a share of GNP, and domestic government debt denominated in (or linked to) a foreign currency as a share of total domestic government debt. Each of the three components is transformed into an index that can take a value from 0 to 10 . At the end, the composite index allows them to measure the degree of partial dollarization of every country in the sample on a scale that goes from 0 to 30 .

The variety of dollarization prevalent in each country at any point in time is determined on the basis of two separate criteria: the degree of domestic dollarization and the amount of foreign borrowing by the private sector. The determination of the domestic dollarization is based on the ratios: foreign currency deposits to broad money and domestic government debt in foreign currency to total government debt. The countries are later on divided into two groups: those where the two ratios are below $10 \%$ and those where at least one of the two ratios exceeds $10 \%$. As for the private foreign borrowing, Reinhart and alii study the share of private sector debt in total external debt. Here also, the countries are divided into two groups: those where private sector debt accounts for at least $10 \%$ of total external debt, and those where the share is below $10 \%$.

The two combined criteria have allowed Reinhart and alii to classify the dollarized economies into four categories or "types". Countries where domestic and external liability dollarization coexists are classified into Type (I). Countries where the dollarization is mainly domestic (foreign borrowings of the private

${ }^{19}$ The definition of dollarization poses some questions. Till the beginning of the $1990 \mathrm{~s}$, the main characteristic of a dollarized economy was the holding by the domestic agents of foreign currencies and assets specified in foreign currencies in their portfolio. After the financial crisis in Asia in the 1990s, the term "dollarization" and "dollarized economy" began to be used by some economists in order to refer to countries that do not have national currency or that have chosen to replace their national currency with a more stable foreign currency (Calvo, 1999, 2000), (Edwards, 2001), (Salvatore et alii, 2003). During the same period, a third category of researchers studied the issue under the angle of liability dollarization. This trend focused on the role of public and private borrowings in foreign currencies in the vulnerability of emerging economies to external shocks. Reinhart and alii (2003) make a distinction between economies that do not have a national currency and "partially" dollarized economies. Lebanon is a part of the latter category. Thus, a partially dollarized economy is an economy where households and firms hold a part of their portfolios in foreign assets and where the public and private sectors are indebted in foreign currencies. These currencies are not necessarily dollar; it can be any other currency (except for the national currency). This definition excludes therefore totally or officially dollarized countries. In this article, when we talk of dollarization, we are referring to partial dollarization. 
sector are limited) are classified into Type (II). Countries were dollarization is basically external (the domestic dollarization is negligible) and where the private foreign borrowing is not reduced are classified into Type (III). Countries where domestic dollarization is low and where the larger part of the external liabilities belongs to the government are classified into Type (IV).

The work of Reinhart and alii shows that "domestic dollarization has been consistently high in the Middle East since the early 1980s, and in the Transition Economies since the early 1990s" 20.

In accordance with Reinhart and alii, Lebanon is part of the most dollarized countries, with a score of 14. According to their calculations, the Lebanese economy is part of the highly dollarized countries (Type I).

Table (1) : The dollarization of the Lebanese economy, 1996-2001

\begin{tabular}{|c|c|c|c|}
\hline $\begin{array}{c}\text { Foreign currency bank } \\
\text { deposits }\end{array}$ & $\begin{array}{c}\text { Domestic debt in foreign } \\
\text { currency }\end{array}$ & External debt & Composite \\
\hline 6 & 3 & 5 & $\mathbf{1 4}$ \\
\hline
\end{tabular}

Source : According to Reinhart and alii (2003), page 57

\section{A VAR model of the Lebanese economy}

In this Section, we study the international transmission of U.S. monetary shocks to the Lebanese economy with the aid of an econometric approach. Our point of departure is a model of the Lebanese economy. It is a VECM (Vector Error Correction Model) that includes six variables, very close to those estimated by Anderson and alii (2002) for the United States. This model will be identified on the basis of the long term relations suggested by economic theory. The VAR model we have constructed has no other objective but to allow us to treat the issue of the monetary conditions' influence in a simple and concise manner, but nevertheless with sufficient thoroughness. The modeling of shocks and the dynamic behavior of this model must address the standpoint in question.

In this Section, we study the international transmission of monetary shocks to the Lebanese economy with the help of a Lebanese model to which we add the U.S. short-term interest rate. We start with a presentation of the Lebanese VAR model. We examine afterwards the effects of structural shocks and draw conclusions on the international transmission of U.S. monetary shocks to the Lebanese economy.

\footnotetext{
${ }^{20}$ Reinhart and alii (2003), page 16.
} 


\subsection{A VAR structural model}

We use recent econometric studies on non-stationary series suitable for such a situation, particularly the approach developed by Johansen (1995), Amisano and Giannini (1997), and especially Johansen and alii (2001). The multivariate co-integration model, within the framework of vector auto-regressive (VAR) models which they propose, must allow us to determine a relevant model without loss of information (variables in level) and to test different structural hypothesis, owing to systematic recourse to the maximum likehood procedure which proved to be exceptionally well suited to this topic.

The base model is a VAR with $(\mathrm{p}=4+1)$ dimensions, where the structural form equation can be written in a very concise way (ignoring the constant terms):

$$
\mathrm{A}(\mathrm{L}) \mathrm{x}_{\mathrm{t}}=\mathrm{Bu}_{\mathrm{t}}
$$

Where $\mathrm{A}(\mathrm{L})$ is a matrix polynomial in the lag operator $(\mathrm{L}),(\mathrm{B})$ is a diagonal matrix, $\left(\mathrm{x}_{\mathrm{t}}\right)$ is a vector of stochastic variables where $\left[\mathrm{x}_{\mathrm{t}} \mathrm{t}=\left(\mathrm{ext} \mathrm{yt}_{\mathrm{t}} \mathrm{im}_{\mathrm{t}} \mathrm{ipct} \mathrm{it}_{\mathrm{t}}\right)\right]$ which will be explained in further detail later on, $\left(\mathrm{u}_{\mathrm{t}}\right)$ is a structural disturbance vector serially uncorrelated of same dimension, with the diagonal matrix $\left[\operatorname{VAR}\left(\mathrm{u}_{\mathrm{t}}\right)=\Lambda\right]$.

The reduced form equation, with errors conforming to a Gauss distribution, is the following:

$$
\mathrm{x}_{\mathrm{t}}=\mathrm{A}_{1} \mathrm{x}_{\mathrm{t}-1}+\ldots+\mathrm{A}_{\mathrm{k}} \mathrm{x}_{\mathrm{t}-\mathrm{k}}+\mu+\psi \mathrm{D}_{\mathrm{t}}+\mathrm{e}_{\mathrm{t}}
$$

With $(t=1, \ldots, T),(k)$ is the number of legs, $\left(e_{t}\right)$ is a vector of niid $(0, \Sigma)$ error terms, and $\left(D_{t}\right)$ is the vector of non stochastic variables (seasonal coefficients, trend, auxiliary variables) or stochastic variables excluded from co-integration space (variables included in the short-term dynamic, but not in the cointegration space). To simplify, we maintain the trend (1) and a constant $\left(\mathrm{u}_{\mathrm{t}}\right)$. The matrixes (A) contain the coefficients.

Conforming to the theorem of Engle and Granger (1987), the previous model can be reformulated in a version of a Vector Error Correction Model (VECM):

$$
\Delta \mathrm{x}_{\mathrm{t}}=\Gamma_{1} \Delta \mathrm{x}_{\mathrm{t}-1}+\ldots+\Gamma_{\mathrm{k}-1} \Delta \mathrm{x}_{\mathrm{t}-\mathrm{k}+1}+\prod \mathrm{x}_{\mathrm{t}-1}+\mu+\psi \mathrm{D}_{\mathrm{t}}+\mathrm{e}_{\mathrm{t}}
$$

The matrixes $(\Gamma)$ and $(\Pi)$ contain the coefficients; the first are relevant to the short-term relations which are stationary, the second are relevant to the long-term relations which are not. In order to make $[\mathrm{I}(0)]$ the product $\left[\prod \mathrm{x}_{\mathrm{t}-1}\right]$, more homogenous with other terms, while $\left[\mathrm{x}_{\mathrm{t}-1}\right]$ is $[\mathrm{I}(1)]$, we shall introduce the cointegration hypothesis.

The VAR model, described in equation (2), or in equation (3) under the VECM form, is the reduced version of a structural model corresponding to equation (1).

By replacing $\left[\mathrm{B}^{-1} \mathrm{~A}(\mathrm{~L})\right]$ with $[\mathrm{G}(\mathrm{L})]$ in this equation (1), we can write:

$$
\mathrm{G}(\mathrm{L}) \mathrm{x}_{\mathrm{t}}=\mathrm{u}_{\mathrm{t}}
$$

The reduced form equation (2) can be written in the following concise form: 


$$
\mathrm{x}_{\mathrm{t}}=\mathrm{C}(\mathrm{L}) \mathrm{x}_{\mathrm{t}-1}+\mathrm{e}_{\mathrm{t}}
$$

Where $[C(L)]$ is a matrix polynomial in lag operator $(L)$ and $\left(e_{t}\right)$ the residuals, with [VAR $\left(e_{t}\right)=\sum$ ].

If we denote $\left(G_{0}\right)$ as the contemporaneous coefficients matrix and $\left[G_{0}(L)\right]$ as the coefficient matrix in $\mathrm{G}(\mathrm{L})$ without the contemporaneous coefficients $\left(\mathrm{G}_{0}\right)$, we can consider that:

$$
\mathrm{G}(\mathrm{L})=\mathrm{G}_{0}+\mathrm{G}_{0}(\mathrm{~L})
$$

Therefore, the parameters in the structural-form equation and those in the reduced-form equation are related in the following manner:

$$
\mathrm{C}(\mathrm{L})=-\mathrm{G}_{0}^{-1} \mathrm{G}_{0}(\mathrm{~L})
$$

Hence, the relation between the structural disturbances and the reduced form residuals is:

$$
\mathrm{u}_{\mathrm{t}}=\mathrm{Go} \mathrm{e}_{\mathrm{t}}
$$

Which we can equally express as:

$$
\mathrm{Bu}_{\mathrm{t}}=\mathrm{Ao} \mathrm{e}_{\mathrm{t}}
$$

With:

$$
\mathrm{G}_{0}=\mathrm{B}^{-1} \mathrm{~A}_{0}
$$

Which implies:

$$
\sum=\mathrm{G}_{0}{ }^{-1} \Lambda \mathrm{G}_{0}{ }^{-1}
$$

The estimation of the matrixes $(\Lambda)$ is completed with the help of the maximum likehood estimation, under identification restrictions, and a number of other sufficient restrictions ${ }^{21}$. Several ways exist to determine the parameters of the structural form starting from the estimated parameters of the reduced form. The principle consists of setting identification constraints, whether on long-term or instantaneously. In this Section, we will impose restrictions on the contemporaneous coefficient matrix in the structural form, for the reason that long-term constraints are already introduced in the VECM. Two methods allow the establishment of these constraints: the Cholesky decomposition (semi-structural VAR) originally used by Sims (1980), and the structural VAR technique proposed by Sims (1986) and Bernanke (1986). We abide by the first one.

The series $\left(\mathrm{x}_{\mathrm{t}}\right)$ can be, in accordance with the cases under study, up to level when the series are stationary $[\mathrm{I}(0)]$, and of primary difference when the series are not stationary [I(1)], and in deviation compared to the VECM relations when the series are non-stationary and co-integrated, which is the case here. The used residuals will therefore be those of the VECM as was previously mentioned.

\footnotetext{
${ }^{21}$ There are $[\mathrm{n} x(\mathrm{n}+1)]$ parameters to estimate. $\left(\sum\right)$ contains $[\mathrm{n} x(\mathrm{n}+1) / 2]$ parameters. In case $(\Lambda)$ contains the same number of parameters; we must introduce at least $[\mathrm{n} x(\mathrm{n}+1) / 2]$ restrictions. By normalizing to $(1)$ the $(\mathrm{n})$ elements of the $\left(\mathrm{G}_{0}\right)$ diagonal, at least $[\mathrm{n} x(\mathrm{n}-1) / 2]$ restrictions are left to introduce.
} 


\subsection{The data}

The series studied are monthly and extend from January 1993 to December 2004. The exports, imports, national output (coinciding indicator), and interest rates (three-month treasury bonds) come from the official site of Lebanon's Central Bank. The consumption price index comes from the publications of the Consultation and Research Institute.

All the series are of type I(1) or analogous to it according to the tests conducted and have been consequently considered as such.

\subsection{The results}

The identification of shocks has been carried out using the Cholesky decomposition and retaining the order of variables from the most exogenous variable to the least exogenous, i.e. (ext $\left.y_{t} i_{t} i_{i p} i_{t}\right)$. The order of introduction, placing first the variables representative of non-monetary shocks and then those representative of monetary shocks, in conformity with Bernanke and Mihov (1995), allows a primary identification. The equation below explains this identification scheme based on the equation: $\left(\mathrm{Bu}_{\mathrm{t}}=\mathrm{A}_{0}\right.$ $\left.e_{t}\right)$.

$$
\left(\begin{array}{llllll}
\mathrm{b}_{11} & 0 & 0 & 0 & 0 & 0 \\
0 \mathrm{~b}_{22} & 0 & 0 & 0 & 0 & 0 \\
00 \mathrm{~b}_{33} & 0 & 0 & 0 & 0 & 0 \\
000 \mathrm{~b}_{44} & 0 & 0 & 0 & 0 & 0 \\
0000 \mathrm{~b}_{55} & 0 & 0 & 0 & 0 & 0
\end{array}\right)\left(\begin{array}{l}
\mathrm{u}_{\mathrm{ex}} \\
\mathrm{u}_{\mathrm{y}} \\
\mathrm{u}_{\mathrm{im}} \\
\mathrm{u}_{\pi} \\
\mathrm{u}_{\mathrm{MP}}
\end{array}\right)=\left(\begin{array}{ccccc}
1 & 0 & 0 & 0 & 0 \\
\mathrm{a}_{21} & 1 & 0 & 0 & 0 \\
\mathrm{a}_{31} & \mathrm{a}_{32} & 1 & 0 & 0 \\
\mathrm{a}_{41} & \mathrm{a}_{42} & \mathrm{a}_{43} & 1 & 0 \\
\mathrm{a}_{51} & \mathrm{a}_{52} & \mathrm{a}_{53} & \mathrm{a}_{54} & 1
\end{array}\right)\left(\begin{array}{l}
\mathrm{e}_{\mathrm{ex}} \\
\mathrm{e}_{\mathrm{y}} \\
\mathrm{e}_{\mathrm{im}} \\
\mathrm{e}_{\pi} \\
\mathrm{e}_{\mathrm{i}}
\end{array}\right)
$$

The structural shocks, represented by (u), are respectively: external shock (exports), supply shock, output shock (imports), price shock, and monetary policy shock. $\left(\mathrm{e}_{\mathrm{ex}}\right),\left(\mathrm{e}_{\mathrm{y}}\right),\left(\mathrm{e}_{\mathrm{im}}\right),\left(\mathrm{e}_{\pi}\right),\left(\mathrm{e}_{\mathrm{i}}\right)$ are the residuals of the reduced form equations.

What are the effects of shocks?

Having identified the structural shocks, the VAR model is transformed into a vector moving average (VMA) model, which allows us to calculate and to graphically represent the dynamics of different endogenous variables following a structural shock of a size equal to a standard deviation (all the shocks are positive a priori). The graphs of structural shock matrixes present the results with a confidence interval of 5 or $10 \%$. Each line corresponds to the effects on a variable, and each column to the same shock effects on the different variables. 


\section{․ The national model in open economy (graph 2)}

The Lebanese model (graph 3) shows the external influence from an export shock. Following an export shock (transitory), the Lebanese output noticeably increases, while the imports vary slightly and nonsignificantly. After some delay in adjustment (a sign of price rigidity), the consumption price index increases and registers a rising growth ${ }^{22}$, while the domestic interest rate does not vary. Following an output shock (transitory), the Lebanese exports almost do not vary at all, and the imports markedly and immediately increase before decreasing. This result is compatible with the Lebanese economic reality, the exports being positively correlated with the national output.

The consumption price index and the interest rate rise, but non-significantly. Following an import shock (transitory), the output slightly increases ${ }^{23}$, and particularly the consumption price index rises (passthrough). The interest rates do not vary. After a price shock (transitory), the output oscillates nonsignificantly, while the imports ${ }^{24}$ and the domestic interest rates increase ${ }^{25}$. An interest rate monetary shock (permanent) causes a large decrease in the national output, in short-term exports and in imports (which vary parallel to the output as we have indicated earlier). We finally note the presence of the habitual price puzzle.

\section{The international transmission of U.S. monetary shock (graph 3)}

The foreign monetary shock, simulated by the help of the money supply variation in the United States $\left(\Delta \mathrm{M}_{\mathrm{US}}\right)$, does not give any exploitable result ${ }^{26}$. To clear up this difficulty, we shall deal with the issue in another way.

The foreign monetary shock, simulated here by the U.S. federal funds rate ${ }^{27}$ (graph 3 ), has a significant effect. Following this shock, a sign of strength in the American economy, the Lebanese national output decreases in the short term. The Lebanese exports and the consumption price index increase, but very faintly and insignificantly. These results partially corroborate the theoretical advances we have defended in Section (2), mainly focusing on the evolution of the foreign output (Lebanon) after a shock in a large

\footnotetext{
${ }^{22}$ The shortage effect and the activity effect.

${ }^{23}$ Non significant.

${ }^{24}$ Non significant.

${ }^{25}$ Fisher Effect in this last case.

${ }^{26}$ The calculations are available.

${ }^{27}$ We can find an explanation in Goux (2006).
} 
economy like that of the United States. However, the U.S. short-term rates wield little influence over the Lebanese short-term rates (we expected a stronger transmission).

We notice that the shock effect on the Lebanese interest rate is divided into three periods of time:

- A (paradoxical) decrease in the Lebanese interest rate within 3 months;

- A non-significant increase after 4 months and for about 8 months: neutral phase;

- After 1 year, an increase of proportions equal to that of the U.S. initial shock.

These results conform to the Betts and Devereux $(1999,2000)$ analyses on the pricing-to market. In compliance with the literature on international transmission of monetary shocks in PTM, the Lebanese interest rate must remain constant or vary slightly following a U.S. monetary shock. But the conformity stops at the end of the first year. Later on, we find the traditional result, like that observed in Kim's simulations (2001), where the increase is integrally transmitted. We identify this phenomenon as the effect of dollarization.

Further explanation would necessitate taking into account two interest rates; besides that of the treasury bonds in Lebanese Pound, the deposit rate in \$, symbol of dollarization in Lebanon, shall allow us to refine the previous results and to better explain the reverse reaction and the delay. The next paper shall take that into consideration. 


\section{Graph (2): The matrix of structural shocks, the Lebanese model}
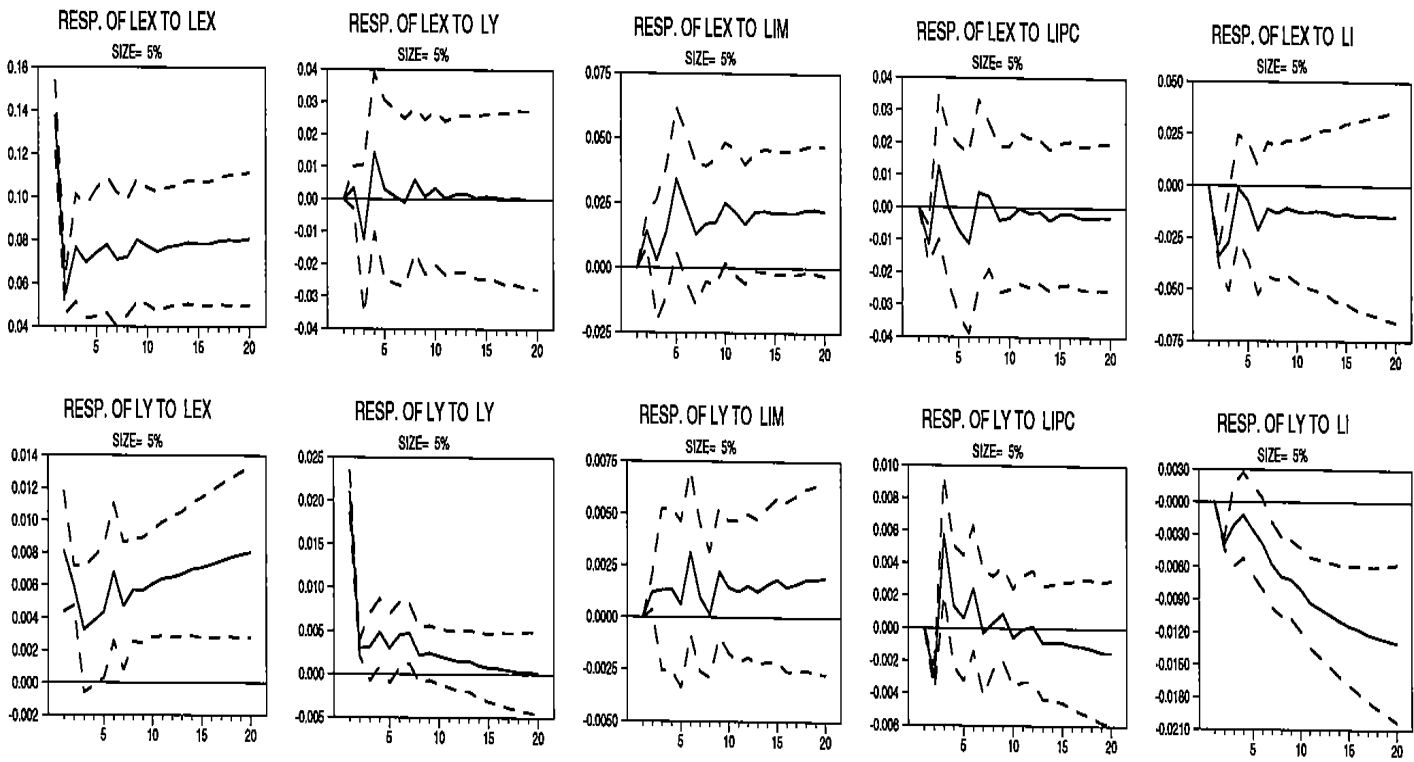

RESP. OF LY TO LI
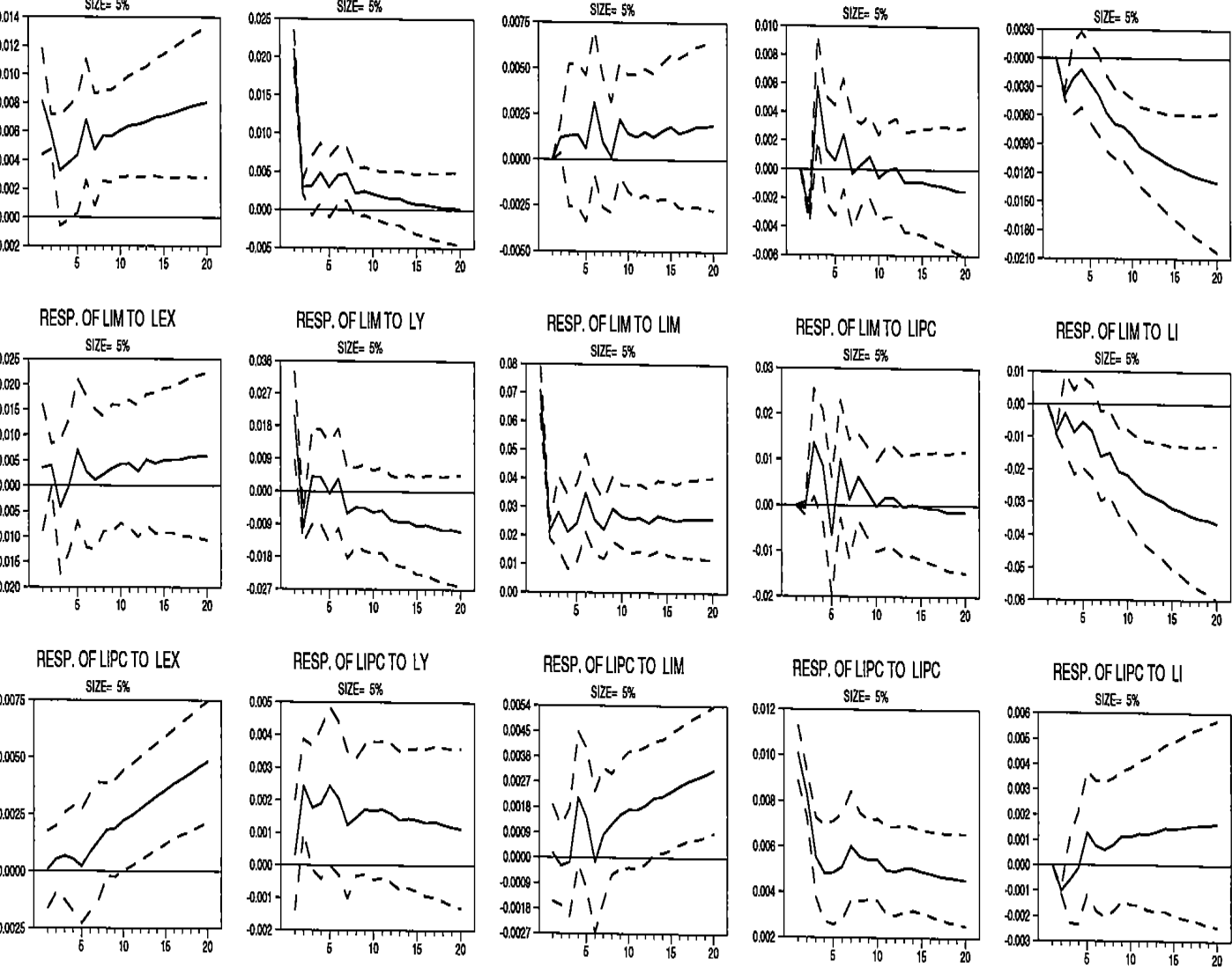

RESP. OF LIPC TO LI
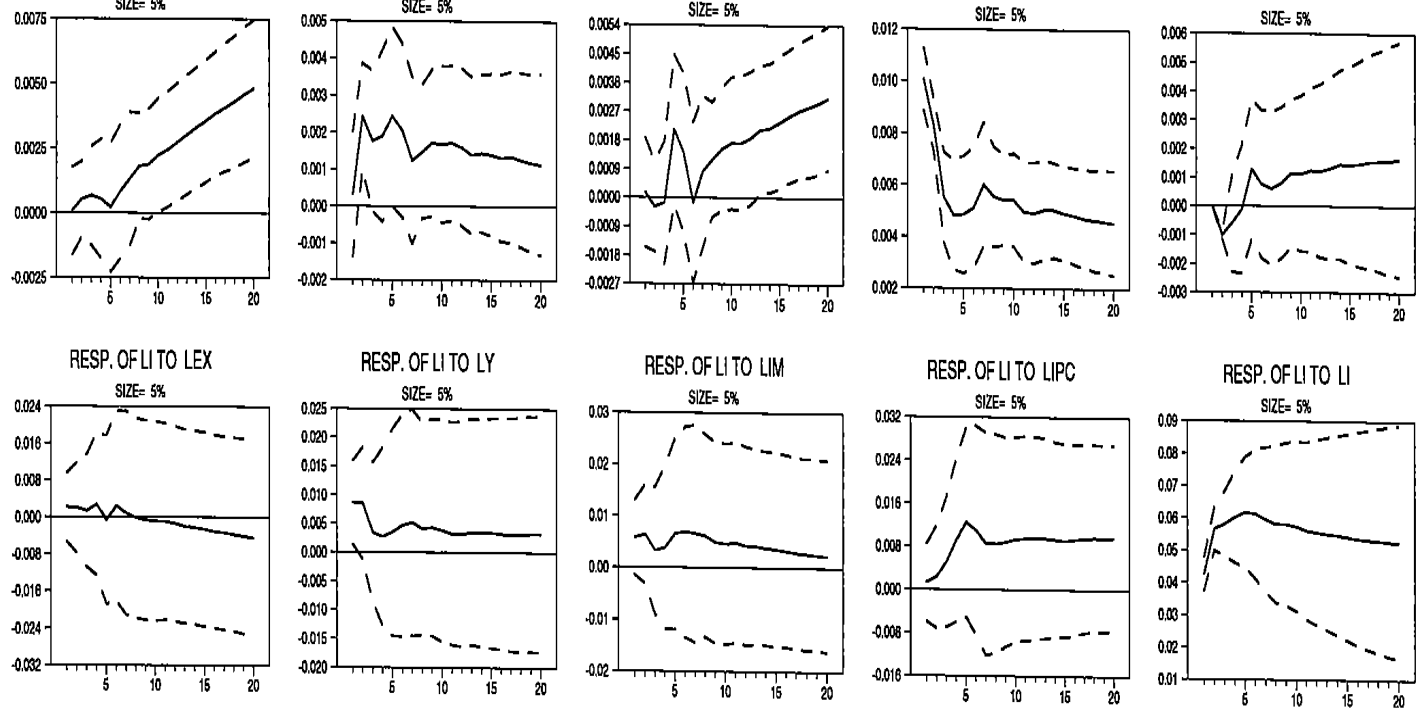


\section{Graph (3): The matrix of structural shocks, the Lebanese model and the Foreign}

\section{(U.S. short-term rate)}
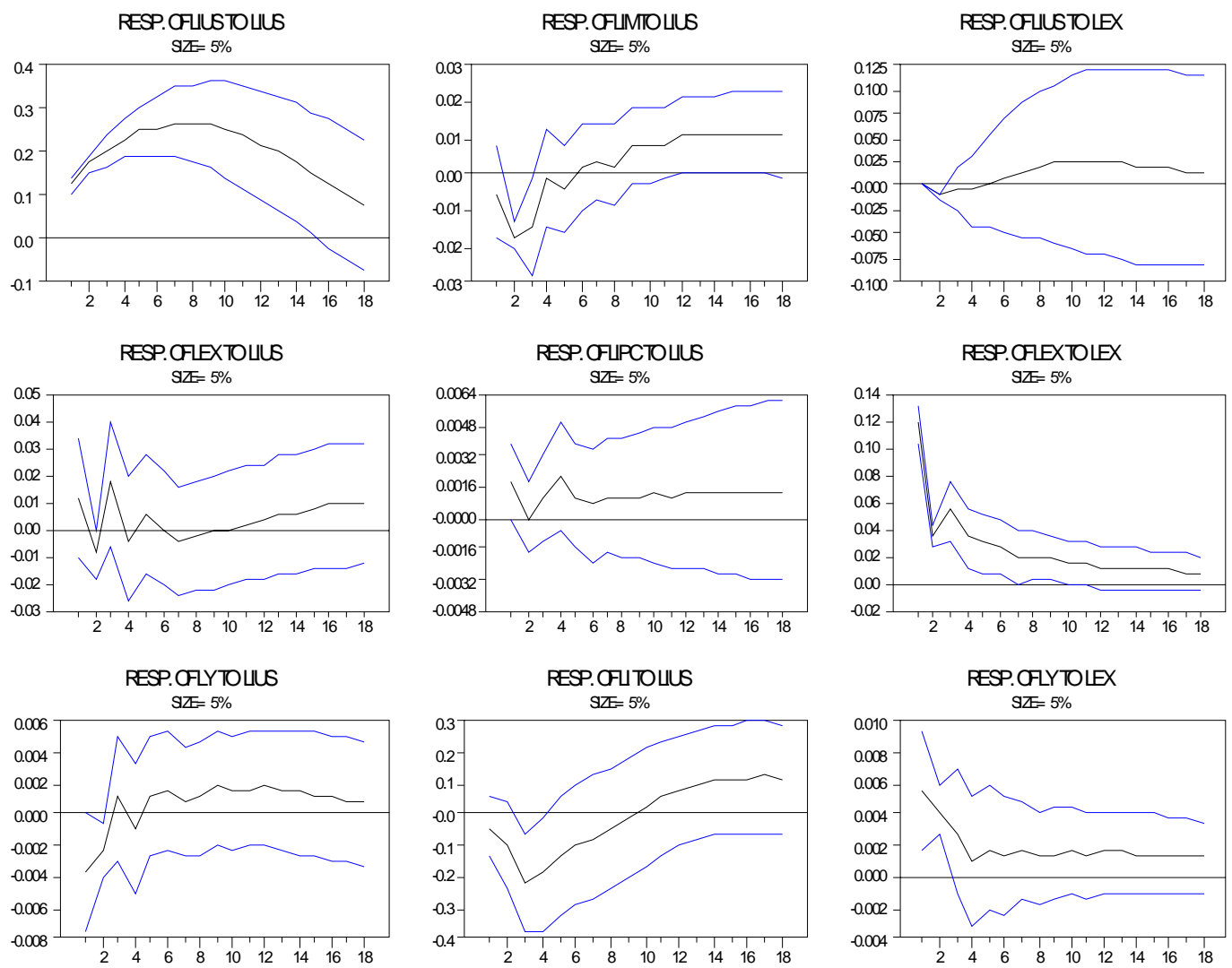

\section{Conclusion}

In conformity with literature advances, an American monetary shock wields an influence, though limited and transitory, over the Lebanese output. Yet, the transmission of the U.S. short-term rates to the Lebanese short-term rates is weak in the first year following the shock. This result can be explained by the existence of pricing-to-market. After the end of the first year, we find the traditional result where the increase in the U.S. interest rate is integrally transmitted to the Lebanese interest rate. We identify this phenomenon as the effect of dollarization. 


\section{References}

- Amisano G. and C. Giannini, 1997. Topics in structural VAR econometrics. Second Edition, Springer Verlag, New York.

- Anderson G., D. Hoffman, and R. Rasche, 2002. A vector-error correction forecasting model in the U.S. economy. Journal of Macroeconomics 24, 569-598.

- Balino T., A. Bennett, and E. Borensztein, 1999. Monetary policy in dollarized economies. IMF Occasional Paper 171, Washington DC.

- Bernanke B.S., 1986. Alternative explanations of the money-income correlation. Carnegie-Rochester Series on Public Policy 25, 49-99.

- Betts C. and M.B. Devereux, 2001. The international effects of monetary and fiscal policy in a twocountry model. Money, Capital Mobility, and Trade: Essays in Honor of Robert A. Mundell. MIT Press, Cambridge, MA, 9-52.

- Betts C. and M.B. Devereux, 2000. Exchange rate dynamics in a model of pricing-to-market. Journal of International Economics 50, 215-244.

- Betts C. and M.B. Devereux, 1999. The international effects of monetary and fiscal policy in a twocountry model. Money, Capital Mobility, and Trade: Essays in Honor of Robert A. Mundell. MIT Press, Cambridge, MA.

- Betts C. and M.B. Devereux, 1996. The exchange rate in a model of pricing-to-market. European Economic Review 40, 1007-1021.

- Blinder A.S., 1994. On sticky prices: academic theories meet the real world. In: N.G. Mankiw, ed., Monetary Policy, Chicago, Chicago University Press, 117-154.

- Calvo G.A., 2000. Capital markets and the exchange rate - with special reference to the dollarization debate in Latin America. Department of Economics, University of Maryland.

- Calvo G.A., 1999. On dollarization. Department of Economics, University of Maryland.

- Calvo G.A. and F. Mishkin, 2003. The mirage of exchange rate regimes for emerging market countries. NBER Working Paper No. 9808.

- Calvo G.A. and C. Reinhart, 1999. Face aux reflux de capitaux, l'arme du taux de change ou la dollarisation. Finances \& Développement.

- Christiano L., M. Eichenbaum, and C. Evans, 1996. The effects of monetary policy shocks: evidence from the flow of funds. Review of Economics and Statistics 78, 16-34.

- Cordahi C., 2005. La transmission internationale des chocs monétaires : le cas du Liban. Ph.D. thesis, Université Lumière Lyon 2, France. 
- Dornbusch R., 1976. Expectations and exchange rate dynamics. Journal of Political Economy 84, 1161-1176.

- Edwards S., 2001. Dollarization: myths and realities. Journal of Policy Modeling 23, 249-265.

- Eichenbaum M. and C. Evans, 1995. Some empirical evidence on the effects of monetary policy shocks on exchange rates. Quarterly Journal of Economics 110, 975-1010.

- $\quad$ Engel C., 1999. Long-run PPP may not hold after all. University of Washington and NBER.

- $\quad$ Engel C. and J. Rogers, 1996. How wide is the border? American Economic Review 86 (5), 11121115.

- Engle R. and C. Granger, 1987. Co-integration and error correction: representation, estimation and testing. Econometrica 55, 251-276.

- Faust J., J.H. Rogers, E. Swanson, and J. Wright, 2003. Identifying the effects of monetary policy shocks on exchange rates using high frequency data. NBER Working Paper No. 9660.

- Gonzalez J., 2000. Exchange rate pass-through and partial dollarization: is there a link? CREDPR Working Paper No. 81, Stanford University.

- Grilli V. and R. Roubini, 1995. Liquidity and exchange rates: puzzling evidence from the G-7 countries. Working Paper, Yale University, CT.

- Guidotti P. and C. Rodriguez, 1992. Dollarization in Latin America: Gresham's law in Reverse. IMS Staff Papers, vol. 38, 518-544.

- Hausmann R., U. Panizza, and E. Stein, 2001. Why do countries float the way they float ? Journal of Development Economics, Elseiver, vol. 66 (2).

- Havrylyshyn O. and C. Beddies, 2003. Dollarization in the former Soviet Union: from hysteria to hysteresis. Comparative Economic Studies 45, 329-357.

- Honohan P. and A. Shi, 2002. Deposit dollarization and the financial sector in emerging economies. Policy Research Working Paper 2748.

- Johansen S., 1995. Likehood-based inference in cointegrated vector auto-regressive models. Oxford, Oxford University Press.

- Johansen S., R. Mosconi, and R. Nielsen, 2001. Cointegration analysis in the presence of structural breaks in the deterministic trend. Econometrics Journal, vol. 3, 216-249.

- Kamin S., 1998. A multi-country comparison of the linkages between inflation and exchange rate competitiveness. Board of Governors of the Federal Reserve System. International Finance Discussion Papers No. 603.

- Kim S., 2001. International transmission of U.S. monetary policy shocks: evidence from VAR's. Journal of Monetary Economics 48, 339-372. 
- Kim S., 1999. Do monetary policy shocks matter in the G-7 countries? Using common identifying assumptions about monetary policy across countries. Journal of International Economics 48, 387412.

- Kim S. and N. Roubini, 2000. Exchange rates anomalies in the industrial countries: a solution with a structural VAR approach. Journal of Monetary Economics 45, 561-586.

- Kollmann R., 1999. Explaining international co-movements of output and asset returns: the role of monetary and nominal rigidities. Working Paper, University of Paris XII, Paris.

- Mongardini J. and J. Mueller, 2000. Ratchet effects in currency substitution: an application to the Kyrgyz Republic. IMF Working Paper No. 102/99.

- Mueller J., 1994. Dollarization in Lebanon. IMF Working Paper WP/94/12, Monetary and Exchange Affairs Department, International Monetary Fund.

- Obstfeld M. and K. Rogoff, 2000. New directions for stochastic open economy models. NBER Working Paper No. 7313.

- Obstfeld M. and K. Rogoff, 1995. Exchange rate dynamics redux. Journal of Political Economy 103, 624-660.

- Ortiz G., 1983. Currency Substitution in Mexico: The Dollarization Problem. Journal of Money, Credit and Banking, vol. 15 (2), 174-185.

- Otani A., 2002. Pricing-to-market (PtM) and the international monetary policy transmission: the « new-open macroeconomics » approach. Institute for Monetary and Economic Studies, Bank of Japan, Japan.

- Ramirez-Rojas C.L., 1985. Currency Substitution in Argentina, Mexico, and Uruguay. IMF Staff Papers, vol. 32 (4), 629-667.

- Reinhart C., 2000. Mirage of Floating Exchange Rates. The American Economic Review 90, No. 2, 65 -70 .

- Reinhart C., K. Rogoff, and M. Savastano, 2003. Addicted to dollars. NBER Working Paper No. 10015.

- Salvatore D., J. Dean, and T. Willett, 2003. The dollarization debate. New York, Oxford University Press.

- Savastano M., 1996. Dollarization in Latin America: recent evidence and policy issues. In: The Macroeconomics of International Currencies: Theory, Policy and Evidence, Edited by P. Mizen and E. Pentecost, 193-224.

- Sims C.A., 1986. Are forecasting models usable for policy analysis? Federal Reserve Bank of Minneapolis Quarterly Review 10, 2-16.

- $\quad$ Sims C.A., 1980. Macroeconomics and reality. Econometrica 48, 1-48. 
- $\quad$ Stockman A. and M. Obstfeld, 1985. Exchange rate dynamics. Jones R., Kenen P., (Eds.), Handbook of International Economics II. North-Holland, Amsterdam.

- Svensson L. and S. Van Wijnbergen, 1989. Excess capacity, monopolistic competition and international transmission of monetary disturbances. Economic Journal 99, 785-805. 